\title{
Alcoholic Liver Disease: Update on the Role of Dietary Fat
}

\author{
Irina A. Kirpich ${ }^{1,2, *}$, Matthew E. Miller ${ }^{1}$, Matthew C. Cave ${ }^{1,2,3}$, Swati Joshi-Barve ${ }^{1,2}$ and \\ Craig J. McClain 1,2,3
}

Received: 31 August 2015; Accepted: 7 December 2015; Published: 6 January 2016

Academic Editors: Natalia Osna and Kusum Kharbanda

1 Division of Gastroenterology, Hepatology and Nutrition, Department of Medicine, University of Louisville School of Medicine, Louisville, KY 40202, USA; millerm25@udayton.edu (M.E.M.); matt.cave@louisville.edu (M.C.C.); swati.joshi-barve@louisville.edu (S.J.-B.); craig.mcclain@louisville.edu (C.J.M.)

2 Department of Pharmacology and Toxicology, University of Louisville School of Medicine, Louisville, KY 40202, USA

3 Robley Rex Veterans Medical Center, Louisville, KY 40202, USA

* Correspondence: I0kirp01@louisville.edu; Tel.: +1-502-608-3331

\begin{abstract}
Alcoholic liver disease (ALD) spans a spectrum of liver pathology, including fatty liver, alcoholic steatohepatitis, and cirrhosis. Accumulating evidence suggests that dietary factors, including dietary fat, as well as alcohol, play critical roles in the pathogenesis of ALD. The protective effects of dietary saturated fat (SF) and deleterious effects of dietary unsaturated fat (USF) on alcohol-induced liver pathology are well recognized and documented in experimental animal models of ALD. Moreover, it has been demonstrated in an epidemiological study of alcoholic cirrhosis that dietary intake of SF was associated with a lower mortality rates, whereas dietary intake of USF was associated with a higher mortality. In addition, oxidized lipids (dietary and in vivo generated) may play a role in liver pathology. The understanding of how dietary fat contributes to the ALD pathogenesis will enhance our knowledge regarding the molecular mechanisms of ALD development and progression, and may result in the development of novel diet-based therapeutic strategies for ALD management. This review explores the relevant scientific literature and provides a current understanding of recent advances regarding the role of dietary lipids in ALD pathogenesis.
\end{abstract}

Keywords: alcoholic liver disease; saturated and unsaturated dietary fat; oxidized dietary lipids; oxidized linoleic acid metabolites; gut microbiota

\section{Introduction}

Alcohol-associated health problems, including alcoholic liver disease (ALD), are a major medical problem within the United States and worldwide. ALD is an umbrella term for the alcohol-induced liver pathology, including fatty liver, alcoholic hepatitis, and cirrhosis, which may further progress to hepatocellular carcinoma. Importantly, clinically important ALD develops only in a subset of people who drink heavily. Alcoholic hepatitis occurs in approximately $10 \%-35 \%$ of chronic drinkers, and severe alcoholic hepatitis accounts for significant morbidity and mortality approaching $35 \%-45 \%$. Approximately $10 \%-20 \%$ of heavy drinkers will develop cirrhosis [1-3]. To date, ALD prevention and treatment strategies have been generally ineffective, in part, due to lack of knowledge regarding the molecular mechanisms underlying ALD development and progression.

Accumulating evidence suggests that dietary factors, including dietary fat, along with heavy alcohol consumption, play critical roles in ALD pathogenesis. Indeed, the beneficial effects of dietary saturated fat (SF) and damaging effects of dietary unsaturated fat (USF, primarily corn oil/linoleic 
acid (LA) enriched) on alcohol-induced liver injury have been documented in experimental animal models of ALD [4-10]. Moreover, comparison of dietary fat intake in various countries with similar per capita alcohol consumption has demonstrated that dietary intake of SF was associated with lower mortality rates, whereas dietary intake of USF was associated with a higher mortality from alcoholic cirrhosis [11]. However, the underlying mechanism(s) by which different types of dietary fat potentiate or attenuate ALD are not completely determined. Understanding of how dietary lipids contribute to ALD pathogenesis will enhance our knowledge regarding the molecular mechanisms of ALD development and progression, and may help to identify novel dietary intervention strategies for ALD prevention/treatment as well as to explain why only some people who drink heavily develop clinically-relevant ALD. The present review summarizes the current knowledge and recent advances regarding the impact of dietary lipids on ALD pathogenesis, including the effects of different types of dietary fat on alcohol-mediated hepatic steatosis, injury, as well as intestinal permeability, endotoxemia, and gut microbiota changes.

\section{Dietary Saturated and Unsaturated Fat: Role in ALD Pathogenesis}

The critical role for the specific types of dietary fat in ALD pathogenesis has been demonstrated and extensively studied in different pre-clinical animal models of ALD using various sources of dietary lipids (e.g., beef fat, cocoa butter, corn oil, fish oil, palm oil, medium chain triglyceride (MCT) oil, Table 1). These diverse dietary lipids have several distinct characteristics, including differences in fatty acid composition, such as carbon chain length (e.g., short, medium and long chain fatty acids), and degree of saturation (e.g., saturated, mono- and polyunsaturated fatty acids, PUFAs, Table 2). In addition, total amount of saturated and unsaturated fatty acids, as well as other compounds (e.g., carotenoids, tocopherols, polyphenols, and glycerol) could also be quite variable between different types of dietary fat. Thus, lard, beef tallow, cocoa butter, and palm oil have a mixture of long-chain saturated fatty acids (mostly C18:0 and C16:0) and monounsaturated fatty acids (primarily C18:1 n9). Corn oil, safflower oil, and soybean oil contain large amount of PUFAs, with the C18:2 n6 as a major PUFA. All the fatty acids in MCT oil are less than 12 carbon saturated fatty acids, with the most abundant being C8:0 fatty acid. It is worth noting that fatty acids with different carbon chain lengths (e.g., long chain vs. medium chain fatty acids) have different metabolic and absorptive pathways. Unlike long chain fatty acids, medium chain fatty acids do not require incorporation into chylomicrons; they are absorbed directly from the diet into the hepatic portal vein. In addition, medium chain fatty acids do not need carnitine acyltransferase for their transport into the inner mitochondria membrane, facilitating rapid transport and oxidation [12]. It has been recently demonstrated that increasing the ratio of MCT oil (rich in medium chain saturated fatty acids) to corn oil (rich in long chain PUFAs) resulted in decreased hepatic steatosis and serum ALT levels in a rat model of non-alcoholic fatty liver disease (NAFLD). This was associated with increased peroxisome proliferator-activated receptor alpha $(\mathrm{PPAR} \alpha)$-dependent hepatic fatty acid oxidation, and reduced membrane susceptibility to free radical attack [13].

The series of initial experimental studies from Nanji's group showed that dietary SF attenuated, and dietary USF, specifically rich in corn oil, promoted alcohol-induced liver damage in experimental animals [14,15]. Moreover, dietary LA (a PUFA with two double bonds, 18:2 n-6), was required for the development of experimental ethanol (EtOH)-induced liver injury; and the severity of ALD was correlated with the amount of LA in the diet [16]. It has also been reported that rats fed EtOH and a diet rich in menhaden fish oil (which contains a large percentage of PUFAs with more than two double bonds) developed pathological changes, including fatty liver, necrosis, and inflammation, even more severe than those fed EtOH and a diet enriched in corn oil [17]. Importantly, dietary SF (e.g., palm oil or MCT oil) reversed the established experimental ALD in rats, and improved liver histologic changes despite continued intragastric EtOH administration [18]. The dose-dependent improvement of EtOH-induced liver pathology and oxidative stress was observed in rats fed alcohol when dietary SF (beef tallow and MCT oil) was substituted for USF (corn oil) at various levels [6] in a dose-dependent 
manner. Dietary supplementation with olive oil, which contains a rich variety of natural antioxidants (e.g., carotenoids, tocopherols, and polyphenols) protected against hepatic lipid peroxidation, leading to a decrease in liver injury in rats chronically exposed to EtOH [19]. A recently-published report has demonstrated that rats fed lard as a source for dietary SF exhibited decreased EtOH-induced hepatic fat accumulation; however, liver necrosis and fibrosis scores were increased in comparison to animals fed $\mathrm{EtOH}$ and a diet containing a combination of corn, olive, and safflower oils [20].

Table 1. The overall effects of different types of dietary fat on EtOH-mediated changes in the intestine and the liver*.

\begin{tabular}{|c|c|c|c|}
\hline Animal Models & Dietary Regimen ** & Significant Outcomes & References \\
\hline $\begin{array}{l}\text { Rats fed EtOH or control liquid diets } \\
\text { with a Ritcher drinking tube for } \\
\text { eight weeks. }\end{array}$ & $\mathrm{CO}+\mathrm{OO}+\mathrm{SFO}$ vs. $\mathrm{L}+\mathrm{SBO} ; 36 \% \mathrm{E}$ & $\begin{array}{l}\text { Hepatic steatosis and inflammation: } \mathrm{CO}+\mathrm{OO}+ \\
\mathrm{SFO}+\mathrm{EtOH}>\mathrm{L}+\mathrm{SBO}+\mathrm{EtOH} \text {; Hepatic fibrosis: } \\
\mathrm{CO}+\mathrm{OO}+\mathrm{SFO}+\mathrm{EtOH}<\mathrm{L}+\mathrm{SBO}+\mathrm{EtOH}\end{array}$ & {$[20]$} \\
\hline $\begin{array}{l}\text { Rats fed intragastrically EtOH or } \\
\text { control liquid diets for four weeks. }\end{array}$ & MCT vs. CO vs. FO; $25 \% \mathrm{E}$ & $\begin{array}{l}\text { Severity of liver pathology: } \mathrm{FO}+\mathrm{EtOH}> \\
\mathrm{CO}+\mathrm{EtOH} ; \mathrm{MCT}+\mathrm{EtOH} \\
\text { (no pathological changes) }\end{array}$ & [15] \\
\hline $\begin{array}{l}\text { Rats fed intragastrically EtOH or } \\
\text { control liquid diets for } 10 \text { weeks. }\end{array}$ & $\begin{array}{l}\mathrm{CO} \text { (USF diet) vs. BT + MCT } \\
\text { (SF diet); } 45 \% \mathrm{E}\end{array}$ & $\begin{array}{l}\text { Liver steatosis, injury, and oxidative stress: } \\
\text { USF + EtOH > SF + EtOH. SF protected rats from } \\
\text { ALD in a dose-responsive fashion }\end{array}$ & [6] \\
\hline $\begin{array}{l}\text { Rats fed solid food and administered } \\
\text { EtOH daily (IP) for six weeks }\end{array}$ & $\begin{array}{l}\mathrm{CO} v s . \mathrm{CO}+\mathrm{OO} \text { supplementation } \\
(5 \% \text { wt/wt) }\end{array}$ & $\begin{array}{l}\text { Liver injury, oxidative stress: } \mathrm{CO}+\mathrm{EtOH}> \\
\mathrm{CO}+\mathrm{OO}+\mathrm{EtOH}\end{array}$ & [19] \\
\hline $\begin{array}{l}\text { Rats fed at libitum EtOH or control } \\
\text { liquid diets for eight weeks. }\end{array}$ & CO vs. CB vs. MCT; $30 \% \mathrm{E}$ & $\begin{array}{l}\text { Liver steatosis, macrophage activation, } \\
\text { neutrophil infiltration, and hepatic endotoxin } \\
\text { levels: } \mathrm{CO}+\mathrm{EtOH}>\mathrm{CB}+\mathrm{EtOH} \text { or } \mathrm{MCT}+\mathrm{EtOH} \\
\text { Serum endotoxin levels: } \mathrm{CO}+\mathrm{EtOH}=\mathrm{CB}+ \\
\text { EtOH; } \mathrm{CO}+\mathrm{EtOH}>\mathrm{MCT}+\mathrm{EtOH}\end{array}$ & [7] \\
\hline $\begin{array}{l}\text { Mice fed intragastrically EtOH or } \\
\text { control liquid diets for three weeks. }\end{array}$ & $\begin{array}{l}\mathrm{CO} \text { (USF diet), } v s \text {. Hydrogenated } \\
\text { soya glyceride ( } 12 \% \text { palmitic and } \\
85 \% \text { stearic acids, SF diet); } 35 \% \mathrm{E}\end{array}$ & $\begin{array}{l}\text { Liver steatosis, injury, and oxidative stress: } \\
\mathrm{USF}+\mathrm{EtOH}>\mathrm{SF}+\mathrm{EtOH}\end{array}$ & [8] \\
\hline $\begin{array}{l}\text { Mice fed at libitum EtOH or control } \\
\text { liquid diets for four weeks. }\end{array}$ & $\mathrm{CO}$ vs. $\mathrm{CB} ; 40 \% \mathrm{E}$ & $\begin{array}{l}\text { Liver injury and steatosis: } \mathrm{CO}+\mathrm{EtOH}> \\
\mathrm{CB}+\mathrm{EtOH} ; \text { Plasma adiponectin: } \\
\mathrm{CO}+\mathrm{EtOH}<\mathrm{CB}+\mathrm{EtOH}\end{array}$ & [9] \\
\hline $\begin{array}{l}\text { Mice fed at libitum EtOH or control } \\
\text { liquid diets for eight weeks. }\end{array}$ & $\begin{array}{l}\text { CO (USF diet) vs. BT + MCT } \\
\text { (SF diet); } 40 \% \mathrm{E}\end{array}$ & $\begin{array}{l}\text { Liver steatosis, inflammation, and injury: } \\
\text { USF + EtOH > SF + EtOH. Intestinal } \\
\text { inflammation, alterations in intestinal tight } \\
\text { junctions, increased gut permeability and } \\
\text { endotoxemia: USF + EtOH > SF + EtOH }\end{array}$ & {$[5,21]$} \\
\hline \multicolumn{4}{|c|}{$\begin{array}{l}\text { Abbreviations: Beef Tallow, BT; Cocoa Butter, CB; Corn Oil, CO; IP, Intraperitoneal Injection; Fish (menhaden) } \\
\text { Oil, FO; Olive Oil, OO; Lard, L; Medium Chain Triglyceride oil, MCT; Safflower Oil, SFO; Sunflower Oil, SnFO; } \\
\text { Soybean Oil, SBO; \%E, percent energy from fat. * The selected studies include different animal models of } \\
\text { ALD (e.g., intragastric vs. ad libitum EtOH administration; rats vs. mice), and different dietary fat sources. } \\
* * \text { The detailed fatty acid composition of fat sources is provided in the Table } 2 .\end{array}$} \\
\hline
\end{tabular}

Table 2. Fatty acid composition of typical fat sources in experimental diets.

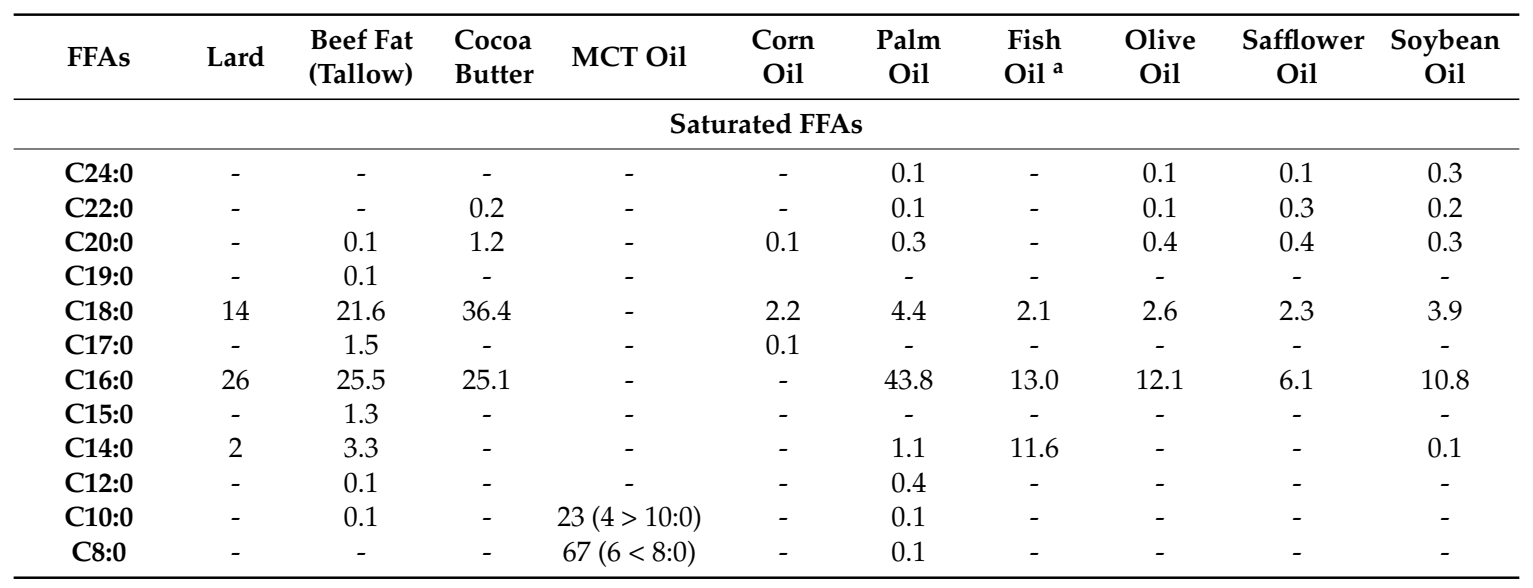


Table 2. Cont

\begin{tabular}{|c|c|c|c|c|c|c|c|c|c|c|}
\hline FFAs & Lard & $\begin{array}{l}\text { Beef Fat } \\
\text { (Tallow) }\end{array}$ & $\begin{array}{l}\text { Cocoa } \\
\text { Butter }\end{array}$ & MCT Oil & $\begin{array}{c}\text { Corn } \\
\text { Oil }\end{array}$ & $\begin{array}{c}\text { Palm } \\
\text { Oil }\end{array}$ & $\begin{array}{l}\text { Fish } \\
\text { Oil }^{a}\end{array}$ & $\begin{array}{c}\text { Olive } \\
\text { Oil }\end{array}$ & $\begin{array}{c}\text { Safflower } \\
\text { Oil }\end{array}$ & $\begin{array}{c}\text { Soybean } \\
\text { Oil }\end{array}$ \\
\hline \multicolumn{11}{|c|}{ Unsaturated FFA (Monounsaturated FFAs) } \\
\hline C24:1 n9 & - & - & - & - & - & - & - & - & 0.2 & - \\
\hline C20:1 n9 & 1 & - & - & - & - & 0.1 & - & 0.3 & 0.2 & 0.1 \\
\hline C18:1 n9 & 44 & 38.7 & 34.1 & - & 27.5 & 39.1 & 6.7 & 72.5 & 13.4 & 23.9 \\
\hline C16:1 & 3 & 3.4 & - & - & 12.2 & 0.2 & 13.3 & 0.8 & 0.1 & 0.2 \\
\hline C15:1 & - & 0.2 & & - & - & - & - & - & - & - \\
\hline C14:1 & - & 0.2 & - & - & - & - & - & - & - & - \\
\hline \multicolumn{11}{|c|}{ Unsaturated FFAs (Polyunsaturated FFAs) } \\
\hline C20:4 n3 & & & & & & & 1.9 & & & \\
\hline C20:4 n6 & - & 0.4 & - & - & - & - & 0.7 & - & 0.5 & - \\
\hline C18:3 n3 & - & 0.6 & 0.2 & - & 0.9 & 0.3 & - & 0.6 & 0.3 & 7.8 \\
\hline C18:2 n6 & 10 & 2.2 & 2.8 & - & 57.0 & 10.2 & 1.1 & 9.4 & 76 & 52.1 \\
\hline References & [22] & [6] & [23] & [6] & [6] & [23] & [15] & [23] & [23] & [23] \\
\hline
\end{tabular}

Based on early studies, the deleterious effects of dietary USF in comparison to protective effects of dietary SF were thought to be mediated through induction of lipid peroxidation and oxidative stress [6,15,24-26], elevated endotoxin levels, and associated increased production of pro-inflammatory cytokines $[4,18,26]$. A number of recent elegant studies have enhanced our knowledge regarding the molecular mechanisms by which dietary USF promotes/exacerbates while the dietary SF prevents/ameliorates ALD. For example, in comparison to dietary USF (corn oil), the beneficial effects of dietary SF (cocoa butter) in ALD was attributed to the modulation of the hepatic SIRT1-SREBP-1-histone H3 (Sirtuin-Sterol Regulatory Element Binding Protein-1c-histone H3) axis, resulting in suppression of genes encoding lipogenic enzymes [27], and the induction of adiponectin, the adipocyte hormone known to play a favorable role in ALD $[9,28]$. The increase in circulating adiponectin was associated with the activation of a set of hepatic signaling pathways mediated through AMP-activated protein kinase (AMPK), PPAR $\alpha$, and peroxisome proliferator-activated receptor gamma coactivator 1 alpha (PGC-1 $\alpha$ ), which, in turn, led to increased rates of fatty acid oxidation, prevention of hepatic steatosis, and attenuation of liver enzyme changes [9]. Another recently identified mechanism of how dietary lipids influence ALD development and progression is through hepatocyte nuclear factor- $4 \alpha(\mathrm{HNF} 4 \alpha)$, a master transcription factor in the regulation of lipid metabolism. It has been reported that EtOH and dietary USF (corn oil) but not SF (MCTs) resulted in increased hepatic fat accumulation in rats in parallel with the decreased levels of HNF4 $\alpha$. The authors postulated that dietary MCTs attenuated alcohol-induced hepatic lipid accumulation, at least partially, through the prevention of HNF4 $\alpha$ reduction [29]. Further, EtOH-mediated reductions in HNF4 $\alpha$ in the intestine were associated with decreased levels of the intestinal tight junction (TJ) proteins and disruption of intestinal barrier integrity [30]. Impaired intestinal barrier integrity is one among several causal factors of alcoholic endotoxemia, a critical factor contributing to the ALD development and progression. There are several lines of evidence suggesting that different types of dietary lipids may differentially modulate EtOH-mediated intestinal barrier disruption, endotoxemia, and subsequent liver injury. Recent studies from our group have demonstrated that eight weeks of EtOH feeding significantly increase liver steatosis, inflammation and injury in mice fed EtOH and USF (corn oil) compared to mice fed EtOH and SF diet containing beef tallow and MCT oil [5]. Hepatic Toll-like receptor mRNA levels (TLR 1, 2, 3, 4, 7, 8, 9) were significantly increased compared to control in the livers of USF + EtOH fed animals, but not in the livers of the $\mathrm{SF}+\mathrm{EtOH}$ group. In parallel with liver injury, significantly 
increased gut permeability and elevated endotoxemia were observed in response to USF + EtOH but not SF + EtOH [5]. Intestinal inflammation was positively correlated with the USF + EtOH triggered disruption of the intestinal TJs. Importantly, USF diet alone resulted in down-regulation of intestinal TJ protein mRNA expression compared to SF. Alcohol further suppressed TJ proteins in USF $+\mathrm{EtOH}$, but not in the SF + EtOH group. Additionally, USF + EtOH, but not SF + EtOH, resulted in alterations of the intestinal mucus layer and intestinal antimicrobial defense [21].

Importantly, the beneficial effects of dietary SF on EtOH-induced liver injury depend on the dietary fatty acid chain length. It has been reported that eight weeks of EtOH plus corn oil feeding to the rats resulted in liver injury with hepatic macrophage activation, increased pro-inflammatory cytokine expression and neutrophil infiltration. These events were not observed in animals fed EtOH and dietary SF, specifically, cocoa butter (rich in long chain saturated fatty acids, palmitic acid (C16:0), and stearic acid (C18:0)) or MCTs (predominantly octanoic (C8:0), and decanoic (C10:0) acids) [7]. Further, endotoxemia was observed in response to EtOH plus corn oil, but not to either cocoa butter or MCTs. On the mechanistic level, MCTs prevented down regulation of intestinal TJ proteins, while cocoa butter normalized EtOH-increased hepatic endotoxin levels via up-regulation of an endotoxin detoxifying enzyme, argininosuccinate synthase 1 [7]. Another recent study has demonstrated that mice supplemented with saturated long chain fatty acids (LCFA, palmitic acid (C16:0, 25\%), and stearic acid (C18:0, 85\%)) developed less severe EtOH-associated liver disease, and these mice had reduced levels of hepatic injury, steatosis, and oxidative stress compared to mice fed EtOH and a diet rich in USF (oleic acid (C18:1, 27\%), and linoleic acid (C18:2, 60\%)) [8]. LCFA supplementation could stabilize the gut barrier, reduce EtOH-mediated intestinal inflammation, and reduce microbial translocation. The authors concluded that these are the factors contributing to the protective effects of LCFA against EtOH-induced liver injury.

\section{Dietary PUFAs and ALD: The Bad, the Good, and the Controversy}

It is important to note that not all dietary PUFAs play an equal role in ALD pathogenesis. There are two major families of dietary PUFAs, specifically omega-6 ( $\omega-6)$ and omega-3 ( $\omega-3)$ PUFAs, with numerous related metabolites (Figure 1). Although the large body of experimental evidence suggests that dietary LA, an omega-6 PUFA (18:2 $\omega-6)$, exacerbates ALD [4-7,16], the role of omega-3 PUFAs, e.g., alpha linolenic acid (ALA, (18:3w-3)), eicosapentaenoic acid (EPA, (20:5w-3)) and docosahexaenoic acid (DHA, (22:6w-3)) in ALD is not completely understood. In general, $\omega-3$ PUFAs, specifically EPA and DHA, are known to have important biological effects on a range of cellular functions resulting in beneficial effects on health, including reduced risk of cardiovascular disease and inflammation [31-35]. It is increasingly recognized that the Western type diet is low in $\omega-3$ PUFAs and rich in $\omega-6$ PUFAs [36], which results in an increased $\omega-6 / \omega-3$ PUFA intake ratio (Table 3). Dietary imbalance between $\omega-6$ and $\omega-3$ PUFAs leads to adverse health effects, including NAFLD [37,38]. There is evidence that $\omega-3$ PUFA supplementation resulted in a reduced plasma $\omega-6 / \omega-3$ ratio [39] and ameliorated hepatic steatosis in patients with NAFLD $[40,41]$. In rodents, $\omega-3$ PUFA depletion promotes hepatic fat accumulation and insulin resistance [42], while $\omega-3$ PUFA supplementation significantly decreased [43-46] or reversed high-fat diet induced liver steatosis [47]. Recent molecular and cellular advances provided new mechanistic insight into the role of specific PUFAs in liver pathology. For example, supplementation of highly purified EPA significantly ameliorated hepatic fat accumulation by inhibition of lipogenesis via suppressing SREBP-1 [45]. The combination of EPA and DHA either reduced or normalized to control values high fat diet-induced hepatic oxidative stress, steatosis (via PPAR $\alpha$ up-regulation), and inflammation (via nuclear factor kappaB (NF-kappaB) DNA binding abrogation) [43,46].

The results regarding the role of dietary $\omega-3$ PUFAs in ALD are somewhat inconsistent. It has been shown that a diet containing fish oil, specifically menhaden fish oil, promotes severe liver injury and inflammation in the EtOH feeding rat model $[17,48]$. These effects were attributed to markedly enhanced hepatic cytochrome P450 2E1 (CYP2E1) levels and lipid peroxidation. On the other hand, there are several studies demonstrating that fish oil or purified $\omega-3$ PUFAs (e.g., EPA and DHA) are 
beneficial in ALD [49-51]. For example, prior ingestion of fish oil, specifically tuna fish oil (30\% of total energy), reduced hepatic fat accumulation caused by a single dose of ethanol administration in mice, at least in part, through a marked reduction in hepatic stearoyl-CoA desaturase-1 (SCD-1) expression and SREBP-1 activity [49]. Another study reported that compared to the control (EtOH-alone) group, the mice supplemented with highly purified DHA had significantly decreased EtOH-induced serum alanine aminotransferase (ALT) activity, pro-inflammatory cytokine levels (interleukin 6 (IL-6) and tumor necrosis factor $\alpha(\mathrm{TNF}-\alpha))$, and were protected against fat accumulation in the livers [51]. This study has also demonstrated that hepatic SCD-1 expression and activity were significantly reduced, whereas the expression of heme oxygenase-1 (HO-1), an enzyme that can improve cell survival in liver tissue, was markedly increased in DHA-supplemented mice compared to the control animals [51]. It has also been reported that rats fed a diet supplemented with physiologically relevant concentrations of w-6 PUFAs, arachidonic acid (AA, (20:4w-6)) and the $\omega-3$ PUFA, DHA (AA:DHA = 1:1), were protected against EtOH-induced fatty liver and mitochondrial dysfunction, most likely through reducing oxidative/nitrosative stress [50]. The beneficial role of $\omega-3$ PUFAs in ALD has been also supported by the observation that when rhesus monkeys were fed a diet that was generally nutritionally adequate (including the LA amount), but had a low $\omega-3$ PUFA content (very low concentration of ALA) with a free access to an ethanol solution, they developed hepatic steatosis and fibrosis [52,53]. It could be speculated that the discordant results regarding the role of $\omega-3$ PUFAs in experimental ALD may reflect the differences in the amounts used to supplement the experimental diets (e.g., large amount in the study demonstrating damaging effects [17] vs. small or physiologically relevant $\omega-3$ PUFA quantities in the studies reporting protective effects [50]). Moreover, the fish oil source, with a variable content of EPA and DHA, may also play a role. In addition, the controversy might also be attributed to the nature of fish oil, which contains large amounts of highly unstable, easily oxidized ex vivo long-chain $\omega-3$ PUFAs. It has been suggested that ingestion of lipid peroxidation products present in oxidized fish oil may cause negative health effects [54]; the oxidation status of the fish oil in the reviewed studies has not been considered. Lastly, the PUFA $\omega 3 / \omega 6$ ratio in a diet needs to be taken into consideration as an important factor contributing to the beneficial or adverse health effects.

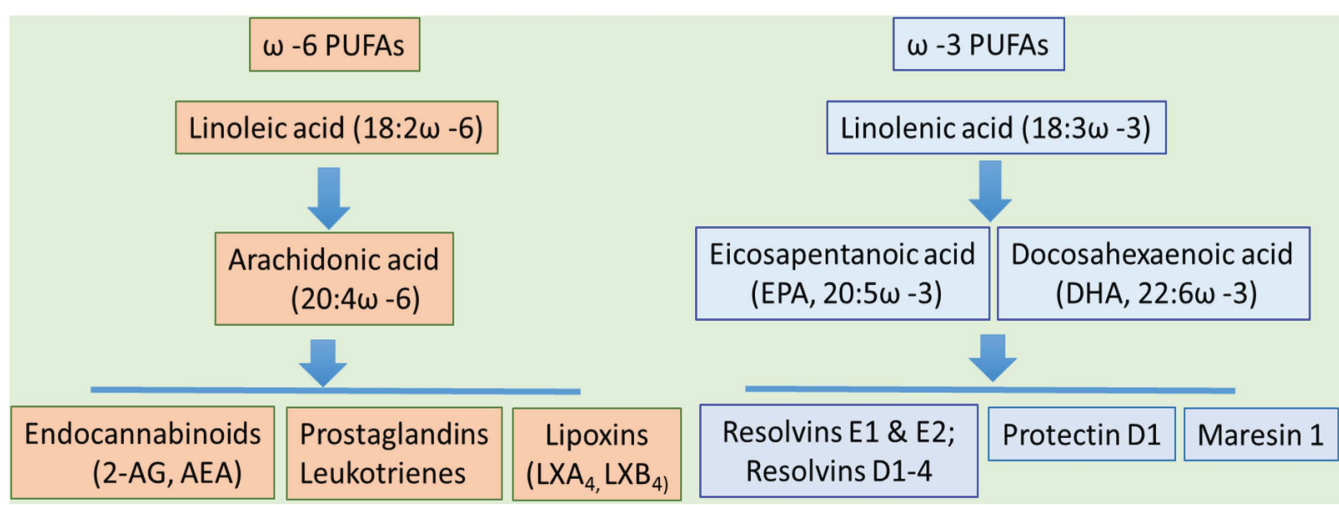

Figure 1. Omega $\omega-6$ and $\omega-3$ essential fatty acids and their metabolites. Abbreviations: AEA: $\mathrm{N}$-arachidonoylethanolamine (anandamide); 2-AG: 2-arachidonoylglycerol; $\mathrm{LXA}_{4}$ : $\operatorname{lipoxin} \mathrm{A}_{4} ; \mathrm{LXB}_{4}$ : lipoxin $\mathrm{B}_{4}$; PUFA: polyunsaturated fatty acid. 
Table 3. Food sources and dietary intake of major $\omega-3$ and $\omega-6$ fatty acids *

\begin{tabular}{|c|c|c|}
\hline Fatty Acids & Food Sources & Dietary Intake \\
\hline \multicolumn{3}{|c|}{ w3 PUFAs } \\
\hline$\alpha$-Linolenic Acid, 18:3 $\omega-3$ & Vegetable oils (e.g., soybean and canola). Nuts, and seeds. & $1.4 \mathrm{~g} / \mathrm{d}$ \\
\hline Eicosapentanoic acid, 20:5 $\omega-3$ & \multirow{2}{*}{ Fish (e.g., halibut, mackerel, herring, and salmon) and fish oils } & \multirow{2}{*}{$0.1-0.2 \mathrm{~g} / \mathrm{d}$} \\
\hline Docosahexaenoic acid, 22:6 $\omega-3$ & & \\
\hline \multicolumn{3}{|c|}{ w6 PUFAs } \\
\hline Linoleic Acid, 18:2 $\omega-6$ & $\begin{array}{l}\text { Vegetable oils (e.g., sunflower, safflower, soybean, corn, and } \\
\text { canola), nuts, seeds meats, and eggs }\end{array}$ & $12-17 \mathrm{~g} / \mathrm{d}$ \\
\hline
\end{tabular}

\section{Oxidized Dietary Fat: Relevance to Liver Pathology}

The Western diet contains large quantities of oxidized lipids, including oxidized fatty acids, oxidized cholesterol, cytotoxic aldehydes, and phospholipids that are formed during different cooking processes (e.g., using a variety of vegetable oils for deep frying, repeated heating) or long term storage [54,57-59]. Moreover, natural antioxidants (e.g., phenols, vitamin E, and other tocopherols) in the oils also deteriorate after heating $[57,60]$. There are numerous factors affecting the quality of oil during deep frying, including the type and quality of frying oil, replenishment of fresh oil, frying time and temperature, and food antioxidants [57]. It is not in the scope of this review to discuss the chemistry of lipid peroxidation, but rather to draw attention to the significance of dietary oxidized lipids in human health and disease [61,62], including their role in ALD pathogenesis. It should be mentioned that no dietary recommendations regarding the toxic or nontoxic amounts of oxidized lipids have been established.

Increasing evidence suggests that oxidized lipids from dietary heated oils contribute to numerous adverse health effects, such as postprandial oxidative stress and inflammatory response [60,63], and cardiovascular disease [62]. There are limited data regarding the effects of oxidized dietary lipids on the liver pathology. It has been reported that rats fed a diet rich in thermally-oxidized palm oil $\left(150^{\circ} \mathrm{C}\right.$, five rounds for $20 \mathrm{~min}$ each) developed more severe liver injury (assessed by significant increase in ALT levels) compared to animals fed a diet containing fresh palm oil [64]. Thermally-oxidized corn oil $\left(180^{\circ} \mathrm{C}\right.$ for $\left.18 \mathrm{~h}\right)$ also induced hepatic lipid peroxidation [65], and liver steatosis and injury in rats [66]. In regard to ALD, it has been shown that the rats, given $\mathrm{EtOH}$ and a diet containing thermally treated sunflower oil $\left(180^{\circ} \mathrm{C}\right.$, two rounds for $\left.30 \mathrm{~min}\right)$ developed more severe liver injury compared to animals given either EtOH or thermally treated sunflower oil alone [67-70]. Liver injury in these animals was attenuated by Phyllanthus niruri (a potent natural antioxidant) leaf extract [71]. Conversely, another study demonstrated that feeding EtOH and a diet containing oxidized sunflower oil $\left(60^{\circ} \mathrm{C}\right.$ for $\left.25 \mathrm{~d}\right)$ compared to EtOH and a diet containing unheated oil resulted in markedly lower liver fat accumulation in rats via a mechanism involving an increase in the expression of PPAR $\alpha$ target genes [72]. However, the effects of oxidized lipids on EtOH-mediated liver injury and inflammation in this animal model remain unclear as no data were provided. Future studies determining the role and underlying mechanisms of either harmful or potentially beneficial effects of oxidized dietary lipids on human health and disease, including liver pathology are warranted.

\section{Oxidized Linoleic Acid Metabolites: Implication for ALD}

Given that: (i) dietary LA is required for the development of experimental ALD [16]; (ii) LA is a major unsaturated fatty acid in the Western diet [55]; and (iii) LA consumption has dramatically increased during the 20th century with the soybean oil, poultry, and shortening as the primary dietary LA sources [36], it is important to determine the mechanisms underlying the deleterious effects of dietary LA on EtOH-mediated liver injury. Based on several observations made in NAFLD and ALD, in both clinical and pre-clinical studies, a new concept has recently emerged that bioactive oxidized 
linoleic metabolites (OXLAMs), which are formed enzymatically from LA primarily via the actions of 12/15-lipoxygenase (12/15-LOX), or non-enzymatically via free radical-mediated oxidation in response to oxidative stress (Figure 2), might contribute to ALD pathogenesis. It has been demonstrated that OXLAMs, specifically 9- and 13-hydroxy-octadecadienoic acids (9- and 13-HODEs), were selectively elevated without corresponding increases in oxidation products of other fatty acids in patients with nonalcoholic steatohepatitis [73], and decreases in plasma OXLAM levels correlated with hepatic histological improvement [74]. Elevated plasma 9- and 13-HODEs levels in patients with alcoholic cirrhosis were observed in parallel with the increase in lipoxygenases (15-LOX-1 and 15-LOX-2 mRNA) in the liver samples [75]. Notably, the plasma content of HODEs in patients with ALD was more than 46 times higher than in healthy subjects and more than four times higher than in NAFLD patients [75]. Further, increased levels of 9- and 13-HODEs were observed in experimental animal models of ALD [76,77] in parallel with the hepatic steatosis, oxidative stress and hepatocyte damage. It has been reported that 9- and 13-HODEs are natural endogenous ligands for the Transient Receptor Potential Vanilloid 1 (TRPV1) [78,79]. Our recent study demonstrated that chronic-binge EtOH-mediated increases in circulating OXLAMs and TRPV1 levels in mice were associated with hepatic steatosis, inflammation, and injury [77]. Importantly, we found that TRPV1 deficiency protected against chronic-binge alcohol induced hepatic inflammation and injury with no effects on hepatic steatosis suggesting that OXLAM/TRPV1 interactions may contribute to the progression from the simple steatosis to steatohepatis (Figure 3). The detailed mechanism(s) remain to be determined. Taken together, OXLAMs might be the metabolites underlying pathogenic effects of dietary USF on EtOH-mediated liver injury via OXLAM/TRPV1-mediated or other mechanism(s); this hypothesis needs to be investigated further.

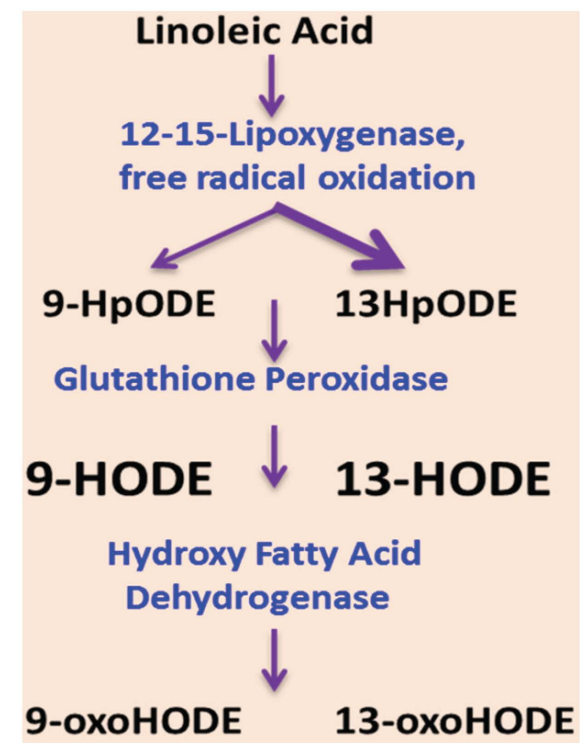

Figure 2. Oxidative metabolism of linoleic acid. LA can be enzymatically or non-enzymatically converted to 9- and 13-HpODE, with subsequent enzymatic conversion to hydroxy (9- and 13-HODE) and ketone (9- and 13-oxoODE) derivatives. Abbreviations: HpODE: hydroperoxy-octadecadienoic acid; HODE: hydroxy-octadecadienoic acid; oxoODE: oxo-octadecadienoic acid. 


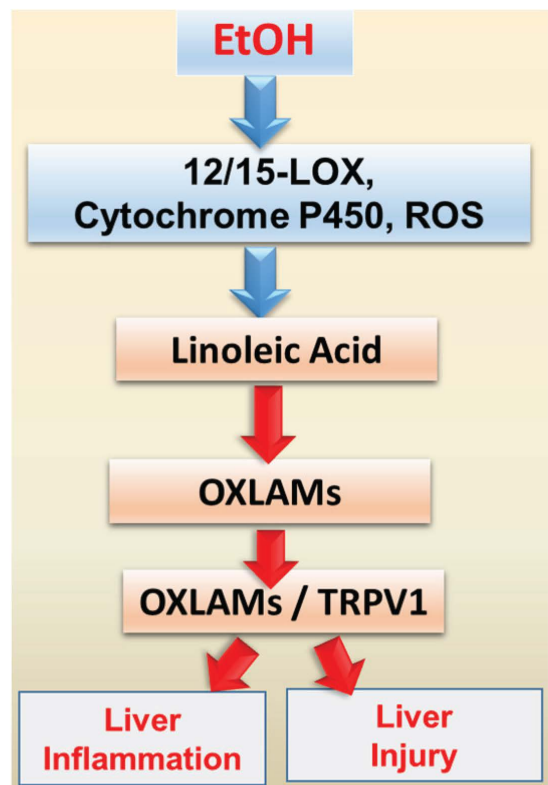

Figure 3. Proposed model of OXLAM/TRPV1-mediated mechanism of USF and EtOH-mediated liver injury and inflammation. Abbreviations: EtOH: ethanol; LOX: lypoxygenase; ROS: reactive oxygen species; OXLAMs: oxidized linoleic metabolites; TRPV1: Transient Receptor Potential Vanilloid 1.

\section{Dietary Fat and EtOH-mediated Changes in the Gut Microbiota}

Over the past decade, the intestinal microbiota have been increasingly recognized as a critical factor in the pathogenesis of ALD. The gastrointestinal microbiome is composed of trillions of organisms [80], which perform a diverse range of metabolic functions [81], including production of numerous metabolites that serve as the nutritional source for microbes as well as important messengers between the microbiota and the host [82]. Several recent studies have shown that alcohol consumption is associated with alterations in the gut microbiota community, changes in microbial metagenome (collective genome of the bacterial community) and the metabolome (small molecule metabolites produced by microbiota), which may contribute to the dysregulated gut-liver axis, thereby exacerbating alcohol-induced liver inflammation and injury [8,83-89]. Both alcohol and diet play pivotal roles in ALD pathogenesis, therefore it is important to consider that the dietary patterns and dietary factors per se play a critical role in shaping the gut microbiota [90-96]. Diet can have a significant impact on the gut environment (e.g., gut transit time and $\mathrm{pH}$ ), and intakes of major macronutrients (carbohydrates, proteins and fats) can significantly affect the microbiota composition. For example, a recent study reported that the Western diet, which is a high saturated fat/high-sugar diet, substantially affects the human microbiome composition and metabolic function [96]. The effects of specific dietary fat on the gut microbiome have been demonstrated in animal models; for example, a high fat saturated diet containing palm oil (palmitic and oleic acids are the major components) reduced microbial diversity and increased the Firmicutes/Bacteroidetes ratio [93]. Another study reported a decrease in Bacteroidetes and an increase in both Firmicutes and Proteobacteria associated with switching to the high saturated fat diet containing lard (pork fat; $\approx 40 \%$ saturated fatty acids, $45 \%$ monounsaturated fatty acids) [90]. There are few studies investigating the effects of different types of dietary fat on the alcohol-mediated changes in the gut microbiota. A recent study from our group demonstrated that chronic EtOH and USF (corn oil/LA rich) feeding in mice caused a decline in the abundance of both Bacteriodetes and Firmicutes phyla, with a proportional increase in the gram-negative Proteobacteria and gram-positive Actinobacteria phyla; these events were associated with disruption of the intestinal barrier, endotoxemia, liver steatosis, inflammation, and injury [86]. These microbiota alterations, and pathological changes in the intestine and the liver were prevented in EtOH and SF (MCT rich diet) fed 
mice (Kirpich I. et al., [97]). It has also been reported that EtOH and a diet supplemented in saturated LCFA (rich in palmitic and stearic acids) maintained intestinal eubiosis compared to mice fed $\mathrm{EtOH}$ and USF diet (rich in oleic acid and LA), in which the microbial dysbiosis characterized by reduced proportion of the Firmicutes, increased numbers of Bacteriodetes, and reduced proportion of Lactobacillus species [8]. Notably, the USF + EtOH induced microbial dysbiosis was associated with intestinal barrier dysfunction and liver injury, which were prevented by LCFA supplementation. The authors further determined that EtOH-mediated intestinal dysbiosis resulted in reduced capacity of the microbiome to synthesize saturated LCSFs that are essential for growth of Lactobacillus, which appears to produce factors that promote proper intestinal barrier function [8]. To summarize, chronic alcohol consumption is accompanied by alterations of gut microbiota composition and metabolic functionality, and dietary factors likely play a critical role in shaping of these changes. Further research is required to define the interactions between the specific types of dietary lipids, the gut microbiota, and ALD development and progression.

\section{Therapeutic Implications of Dietary Lipids in ALD}

If validated in human studies, the cumulative experimental dietary data have important implications for ALD including prevention and treatment. Dietary factors such as specific unsaturated fats may help explain why only some people who drink heavily develop progressive ALD. Dietary restriction of potentially "harmful" lipids could help prevent ALD in those who drink heavily (although this is probably unrealistic). For patients with ALD who are prescribed or take nutritional supplements, the optimal lipid composition may include MCTs (indeed, they are already used in many enteral products). The American Society of Parenteral and Enteral Nutrition identified MCT oil as a potentially beneficial additive to the lipid emulsions for the parenteral nutrition [98]. "Nutritional" drugs such as tributyrin (prodrug of butyrate, a short chain fatty acid) may be beneficial in ALD. Indeed, a pre-clinical experimental study has recently demonstrated that tributyrin prevented short-term EtOH-induced increases in ALT and hepatic pro-inflammatory cytokine and chemokine expression, and protected mice from acute ethanol-induced gut injury [99]. Thus, there are multiple "lipid interventions" that may prove beneficial in ALD.

\section{Conclusions}

In conclusion, there is convincing experimental evidence demonstrating the differential effects of different types of dietary lipids in the pathogenesis of ALD. While the protective effects of dietary SF and deleterious effects of dietary USF (primarily rich in LA, an $\omega-6$ PUFA) on ethanol-induced intestinal and liver injury have been well documented in animal models (Figure 4), the effects of dietary $\omega-3$ PUFAs as well as the significance of the dietary PUFA $\omega-3 / \omega-6$ ratio in ALD development and progression are not completely understood. The role and the significance of oxidized lipids, both dietary and in vivo-produced, as well as possible mechanisms underlying their beneficial or deleterious effects in liver pathology remain to be determined. Different types of dietary fat may differentially modulate the gut-liver axis, including EtOH-induced changes in the gut microbiota. This important aspect needs to be considered when evaluating the effects of EtOH consumption on the gut microbiota composition and function. Given that there is no FDA-approved therapy for any stage of ALD, dietary fat may play an important role in the management of ALD. 


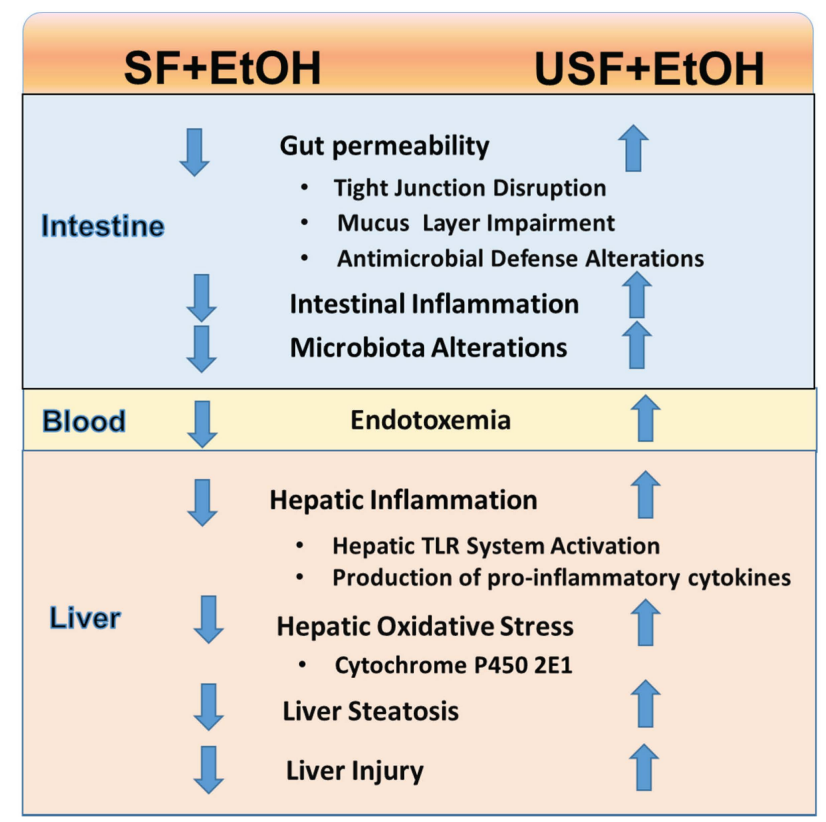

Figure 4. Differential effects of dietary saturated and unsaturated fat on EtOH-induced intestinal and liver alterations.

Acknowledgments: The authors thank Marion McClain for proofreading the manuscript. Funding: The work presented in this study was supported by NIH grants R21 AA020849-01A1 (Irina A. Kirpich), K23AA18399 (Matthew C. Cave), R01ES021375 (Matthew C. Cave), 1UO1AA022489 (Craig J. McClain), 1U01AA021901-01 (Craig J. McClain), 1U01AA021893-01 (Craig J. McClain), R01 AA023681 (Craig J. McClain), R01 AA018869 (Craig J. McClain), the Department of Veterans Affairs BX000350 (Craig J. McClain), and the Department of Defense W81XWH-11-1-0595 (Craig J. McClain).

Author Contributions: All authors contributed to the present review-Irina A. Kirpich: design, data collection, writing and critical reading; Matthew E. Miller: data collection; Matthew C. Cave: design and critical reading; Swati Joshi-Barve: design and critical reading; Craig J. McClain: design and critical reading.

Conflicts of Interest: The authors have no conflict of interest to declare.

\section{Abbreviations}

$\begin{array}{ll}\text { AA } & \text { arachidonic acid } \\ \text { AEA } & N \text {-arachidonoylethanolamine (anandamide) } \\ \text { 2-AG } & \text { 2-arachidonoylglycerol } \\ \text { ALA } & \text { alpha linolenic acid } \\ \text { ALD } & \text { alcoholic liver disease } \\ \text { ALT } & \text { alanine aminotransferase } \\ \text { AMPK } & \text { AMP-activated protein kinase } \\ \text { CYP2E1 } & \text { cytochrome P450 2E1 } \\ \text { DHA } & \text { docosahexaenoic acid } \\ \text { HNF4 } \alpha & \text { hepatocyte nuclear factor-4 } \alpha \\ \text { HO-1 } & \text { heme oxygenase-1 } \\ \text { HpODE } & \text { hydroperoxy-octadecadienoic acid } \\ \text { 9- and 13-HODEs } & 9 \text { - and 13-hydroxy-octadecadienoic acids } \\ \text { EPA } & \text { eicosapentaenoic acid } \\ \text { EtOH } & \text { ethanol } \\ \text { IL-6 } & \text { interleukin } 6 \\ \text { LA } & \text { linoleic acid } \\ \text { LPS } & \text { lipopolysaccharide } \\ \text { 12/15-LOX } & \text { 12/15-lipoxygenase }\end{array}$




$\begin{array}{ll}\text { LCFA } & \text { long chain fatty acids } \\ \text { LXA }_{4} & \text { lipoxin } \mathrm{A}_{4} \\ \mathrm{LXB}_{4} & \text { lipoxin } \mathrm{B}_{4} \\ \text { MCT } & \text { medium chain triglyceride } \\ \text { NAFLD } & \text { nonalcoholic fatty liver disease } \\ \text { NF-kappaB } & \text { nuclear factor kappaB } \\ \text { OXLAMs } & \text { oxidized linoleic acid metabolites } \\ \text { oxoODE } & \text { oxo-octadecadienoic acid } \\ \text { PPAR } \alpha & \text { peroxisome proliferator-activated receptor alpha } \\ \text { PGC-1 } \alpha & \text { peroxisome proliferator-activated receptor gamma, coactivator 1 alpha } \\ \text { PUFA } & \text { polyunsaturated fatty acid } \\ \text { ROS } & \text { reactive oxygen species } \\ \text { SF } & \text { saturated fat } \\ \text { SCD-1 } & \text { stearoyl-CoA desaturase-1 } \\ \text { SIRT1 } & \text { Sirtuin } \\ \text { SREBP-1 } & \text { sterol regulatory element binding protein-1c } \\ \text { TJs } & \text { tight junctions } \\ \text { TG } & \text { triacylglycerol } \\ \text { TLR } & \text { Toll-like receptors } \\ \text { TRPV1 } & \text { Transient Receptor Potential Vanilloid 1 } \\ \text { TNF- } \alpha & \text { tumor necrosis factor } \alpha \\ \text { USF } & \text { unsaturated fat }\end{array}$

\section{References}

1. Rehm, J.; Samokhvalov, A.; Shield, K. Global burden of alcoholic liver disease. J. Hepatol. 2013, 59, $160-168$. [CrossRef] [PubMed]

2. D'Amico, G.; Garcia-Tsao, G.; Pagliaro, L. Natural history and prognostic indicators of survival in cirrhosis: A systematic review of 118 studies. J. Hepatol. 2006, 44, 217-231. [CrossRef] [PubMed]

3. Wakim-Fleming, J.; Mullen, K.D. Long-term management of alcoholic liver disease. Clin. Liver Dis. 2005, 9 , 135-149. [CrossRef] [PubMed]

4. Nanji, A.A. Role of different dietary fatty acids in the pathogenesis of experimental alcoholic liver disease. Alcohol 2004, 34, 21-25. [CrossRef] [PubMed]

5. Kirpich, I.A.; Feng, W.; Wang, Y.; Liu, Y.; Barker, D.F.; Barve, S.S.; McClain, C.J. The type of dietary fat modulates intestinal tight junction integrity, gut permeability, and hepatic toll-like receptor expression in a mouse model of alcoholic liver disease. Alcohol. Clin. Exp. Res. 2012, 36, 835-846. [CrossRef] [PubMed]

6. Ronis, M.J.; Korourian, S.; Zipperman, M.; Hakkak, R.; Badger, T.M. Dietary saturated fat reduces alcoholic hepatotoxicity in rats by altering fatty acid metabolism and membrane composition. J. Nutr. 2004, 134, 904-912. [PubMed]

7. Zhong, W.; Li, Q.; Xie, G.; Sun, X.; Tan, X.; Sun, X.; Jia, W.; Zhou, Z. Dietary fat sources differentially modulate intestinal barrier and hepatic inflammation in alcohol-induced liver injury in rats. Am. J. Physiol. Gastrointest. Liver Physiol. 2013, 305, G919-G932. [CrossRef] [PubMed]

8. Chen, P.; Torralba, M.; Tan, J.; Embree, M.; Zengler, K.; Stärkel, P.; van Pijkeren, J.P.; DePew, J.; Loomba, R.; Ho, S.B.; et al. Supplementation of saturated long-chain fatty acids maintains intestinal eubiosis and reduces ethanol-induced liver injury in mice. Gastroenterology 2015, 148, 203-214. [CrossRef] [PubMed]

9. You, M.; Considine, R.V.; Leone, T.C.; Kelly, D.P.; Crabb, D.W. Role of adiponectin in the protective action of dietary saturated fat against alcoholic fatty liver in mice. Hepatology 2005, 42, 568-577. [CrossRef] [PubMed]

10. Mezey, E. Dietary fat and alcoholic liver disease. Hepatology 1998, 28, 901-905. [CrossRef] [PubMed]

11. Nanji, A.A.; French, S.W. Dietary factors and alcoholic cirrhosis. Alcohol. Clin. Exp. Res. 1986, 10, $271-273$. [CrossRef] [PubMed]

12. Lieber, C.S.; Lefèvre, A.; Spritz, N.; Feinman, L.; DeCarli, L.M. Difference in hepatic metabolism of long- and medium-chain fatty acids: The role of fatty acid chain length in the production of the alcoholic fatty liver. J. Clin. Investig. 1967, 46, 1451-1460. [CrossRef] [PubMed] 
13. Ronis, M.J.; Baumgardner, J.N.; Sharma, N.; Vantrease, J.; Ferguson, M.; Tong, Y.; Wu, X.; Cleves, M.A.; Badger, T.M. Medium chain triglycerides dose-dependently prevent liver pathology in a rat model of non-alcoholic fatty liver disease. Exp. Biol. Med. 2013, 238, 151-162. [CrossRef] [PubMed]

14. Nanji, A.A.; Mendenhall, C.L.; French, S.W. Beef fat prevents alcoholic liver disease in the rat. Alcohol. Clin. Exp. Res. 1989, 13, 15-19. [CrossRef] [PubMed]

15. Nanji, A.A.; Griniuviene, B.; Sadrzadeh, S.M.; Levitsky, S.; McCully, J.D. Effect of type of dietary fat and ethanol on antioxidant enzyme mRNA induction in rat liver. J. Lipid Res. 1995, 36, 736-744. [PubMed]

16. Nanji, A.A.; French, S.W. Dietary linoleic acid is required for development of experimentally induced alcoholic liver injury. Life Sci. 1989, 44, 223-227. [CrossRef]

17. Nanji, A.A.; Zhao, S.; Sadrzadeh, S.M.; Dannenberg, A.J.; Tahan, S.R.; Waxman, D.J. Markedly enhanced cytochrome P450 2E1 induction and lipid peroxidation is associated with severe liver injury in fish oil-ethanol-fed rats. Alcohol. Clin. Exp. Res. 1994, 18, 1280-1285. [CrossRef] [PubMed]

18. Nanji, A.A.; Jokelainen, K.; Tipoe, G.L.; Rahemtulla, A.; Dannenberg, A.J. Dietary saturated fatty acids reverse inflammatory and fibrotic changes in rat liver despite continued ethanol administration. J. Pharmacol. Exp. Ther. 2001, 299, 638-644. [PubMed]

19. Kasdallah-Grissa, A.; Nakbi, A.; Koubaa, N.; El-Fazaâ, S.; Gharbi, N.; Kamoun, A.; Hammami, M. Dietary virgin olive oil protects against lipid peroxidation and improves antioxidant status in the liver of rats chronically exposed to ethanol. Nutr. Res. 2008, 28, 472-479. [CrossRef] [PubMed]

20. Chen, Y.L.; Peng, H.C.; Wang, X.D.; Yang, S.C. Dietary saturated fatty acids reduce hepatic lipid accumulation but induce fibrotic change in alcohol-fed rats. Hepatobiliary Surg. Nutr. 2015, 4, 172-183. [PubMed]

21. Kirpich, I.A.; Feng, W.; Wang, Y.; Liu, Y.; Beier, J.I.; Arteel, G.E.; Falkner, K.C.; Barve, S.S.; McClain, C.J. Ethanol and dietary unsaturated fat (corn oil/linoleic acid enriched) cause intestinal inflammation and impaired intestinal barrier defense in mice chronically fed alcohol. Alcohol 2013, 47, 257-264. [CrossRef] [PubMed]

22. Institute of Shortening and Edible Oils, Inc. Food Fats and Oils. Available online: http://www.iseo.org/ httpdocs/Publications/FoodFatsOils2006.pdf (accessed on 5 May 2015).

23. Dubois, V.; Breton, S.; Linder, M.; Fanni, J.; Parmentier, M. Fatty acid profiles of 80 vegetable oils with regard to their nutritional potential. Eur. J. Lipid Sci. Technol. 2007, 109, 710-732. [CrossRef]

24. Nanji, A.A.; Zhao, S.; Lamb, R.G.; Dannenberg, A.J.; Sadrzadeh, S.M.; Waxman, D.J. Changes in cytochromes $\mathrm{P}-450,2 \mathrm{E} 1,2 \mathrm{~B} 1$, and 4A, and phospholipases $\mathrm{A}$ and $\mathrm{C}$ in the intragastric feeding rat model for alcoholic liver disease: Relationship to dietary fats and pathologic liver injury. Alcohol. Clin. Exp. Res. 1994, 18, 902-908. [CrossRef] [PubMed]

25. Polavarapu, R.; Spitz, D.R.; Sim, J.E.; Follansbee, M.H.; Oberley, L.W.; Rahemtulla, A.; Nanji, A.A. Increased lipid peroxidation and impaired antioxidant enzyme function is associated with pathological liver injury in experimental alcoholic liver disease in rats fed diets high in corn oil and fish oil. Hepatology 1998, 27, 1317-1323. [CrossRef] [PubMed]

26. Kono, H.; Enomoto, N.; Connor, H.D.; Wheeler, M.D.; Bradford, B.U.; Rivera, C.A.; Kadiiska, M.B.; Mason, R.P.; Thurman, R.G. Medium-chain triglycerides inhibit free radical formation and TNF-alpha production in rats given enteral ethanol. Am. J. Physiol. Gastrointest. Liver Physiol. 2000, 278, G467-G476. [PubMed]

27. You, M.; Cao, Q.; Liang, X.; Ajmo, J.M.; Ness, G.C. Mammalian sirtuin 1 is involved in the protective action of dietary saturated fat against alcoholic fatty liver in mice. J. Nutr. 2008, 138, 497-501. [PubMed]

28. You, M.; Rogers, C.Q. Adiponectin: A key adipokine in alcoholic fatty liver. Exp. Biol. Med. 2009, 234, 850-859. [CrossRef] [PubMed]

29. Li, Q.; Zhong, W.; Qiu, Y.; Kang, X.; Sun, X.; Tan, X.; Zhao, Y.; Sun, X.; Jia, W.; Zhou, Z. Preservation of hepatocyte nuclear factor-4alpha contributes to the beneficial effect of dietary medium chain triglyceride on alcohol-induced hepatic lipid dyshomeostasis in rats. Alcohol. Clin. Exp. Res. 2013, 37, 587-598. [CrossRef] [PubMed]

30. Zhong, W.; Zhao, Y.; McClain, C.J.; Kang, Y.J.; Zhou, Z. Inactivation of hepatocyte nuclear factor-4\{alpha\} mediates alcohol-induced downregulation of intestinal tight junction proteins. Am. J. Physiol. Gastrointest. Liver Physiol. 2010, 299, G643-G651. [CrossRef] [PubMed] 
31. Yashodhara, B.M.; Umakanth, S.; Pappachan, J.M.; Bhat, S.K.; Kamath, R.; Choo, B.H. Omega-3 fatty acids: A comprehensive review of their role in health and disease. Postgrad. Med. J. 2009, 85, 84-90. [CrossRef] [PubMed]

32. Lorente-Cebrian, S.; Costa, A.G.; Navas-Carretero, S.; Zabala, M.; Martínez, J.A.; Moreno-Aliaga, M.J. Role of omega-3 fatty acids in obesity, metabolic syndrome, and cardiovascular diseases: A review of the evidence. J. Physiol. Biochem. 2013, 69, 633-651. [CrossRef] [PubMed]

33. Martinez-Fernandez, L.; Laiglesia, L.M.; Huerta, A.E.; Martínez, J.A.; Moreno-Aliaga, M.J. Omega-3 fatty acids and adipose tissue function in obesity and metabolic syndrome. Prostaglandins Other Lipid Mediat. 2015. [CrossRef] [PubMed]

34. Scorletti, E.; Byrne, C.D. Omega-3 fatty acids, hepatic lipid metabolism, and nonalcoholic fatty liver disease. Annu. Rev. Nutr. 2013, 33, 231-248. [CrossRef] [PubMed]

35. Ellulu, M.S.; Khaza'ai, H.; Abed, Y.; Rahmat, A.; Ismail, P.; Ranneh, Y. Role of fish oil in human health and possible mechanism to reduce the inflammation. Inflammopharmacology 2015, 23, 79-89. [CrossRef] [PubMed]

36. Blasbalg, T.L.; Hibbeln, J.R.; Ramsden, C.E.; Majchrzak, S.F.; Rawlings, R.R. Changes in consumption of omega-3 and omega-6 fatty acids in the United States during the 20th century. Am. J. Clin. Nutr. 2011, 93, 950-962. [CrossRef] [PubMed]

37. Zelber-Sagi, S.; Nitzan-Kaluski, D.; Goldsmith, R.; Webb, M.; Blendis, L.; Halpern, Z.; Oren, R. Long term nutritional intake and the risk for non-alcoholic fatty liver disease (NAFLD): A population based study. J. Hepatol. 2007, 47, 711-717. [CrossRef] [PubMed]

38. Russo, G.L. Dietary n-6 and n-3 polyunsaturated fatty acids: From biochemistry to clinical implications in cardiovascular prevention. Biochem. Pharmacol. 2009, 77, 937-946. [CrossRef] [PubMed]

39. Spahis, S.; Alvarez, F.; Dubois, J.; Ahmed, N.; Peretti, N.; Levy, E. Plasma fatty acid composition in French-Canadian children with non-alcoholic fatty liver disease: Effect of n-3 PUFA supplementation. Prostaglandins Leukot. Essent. Fatty Acids 2015, 99, 25-34. [CrossRef] [PubMed]

40. Capanni, M.; Calella, F.; Biagini, M.R.; Genise, S.; Raimondi, L.; Bedogni, G.; Svegliati-Baroni, G.; Sofi, F.; Milani, S.; Abbate, R.; et al. Prolonged n-3 polyunsaturated fatty acid supplementation ameliorates hepatic steatosis in patients with non-alcoholic fatty liver disease: A pilot study. Aliment. Pharmacol. Ther. 2006, 23, 1143-1151. [CrossRef] [PubMed]

41. Nobili, V.; Alisi, A.; Della Corte, C.; Risé, P.; Galli, C.; Agostoni, C.; Bedogni, G. Docosahexaenoic acid for the treatment of fatty liver: Randomised controlled trial in children. Nutr. Metab. Cardiovasc. Dis. 2013, 23, 1066-1070. [CrossRef] [PubMed]

42. Pachikian, B.D.; Essaghir, A.; Demoulin, J.B.; Neyrinck, A.M.; Catry, E.; de Backer, F.C.; Dejeans, N.; Dewulf, E.M.; Sohet, F.M.; Portois, L.; et al. Hepatic n-3 polyunsaturated fatty acid depletion promotes steatosis and insulin resistance in mice: Genomic analysis of cellular targets. PLoS ONE 2011, 6, e23365. [CrossRef] [PubMed]

43. Valenzuela, R.; Espinosa, A.; González-Mañán, D.; D’Espessailles, A.; Fernández, V.; Videla, L.A.; Tapia, G. N-3 long-chain polyunsaturated fatty acid supplementation significantly reduces liver oxidative stress in high fat induced steatosis. PLoS ONE 2012, 7, e46400. [CrossRef] [PubMed]

44. Kajikawa, S.; Harada, T.; Kawashima, A.; Imada, K.; Mizuguchi, K. Highly purified eicosapentaenoic acid ethyl ester prevents development of steatosis and hepatic fibrosis in rats. Dig. Dis. Sci. 2010, 55, 631-641. [CrossRef] [PubMed]

45. Kajikawa, S.; Harada, T.; Kawashima, A.; Imada, K.; Mizuguchi, K. Highly purified eicosapentaenoic acid prevents the progression of hepatic steatosis by repressing monounsaturated fatty acid synthesis in high-fat/high-sucrose diet-fed mice. Prostaglandins Leukot. Essent. Fatty Acids 2009, 80, 229-238. [CrossRef] [PubMed]

46. Tapia, G.; Valenzuela, R.; Espinosa, A.; Romanque, P.; Dossi, C.; Gonzalez-Mañán, D.; Videla, L.A.; D'Espessailles, A. N-3 long-chain PUFA supplementation prevents high fat diet induced mouse liver steatosis and inflammation in relation to PPAR-alpha upregulation and NF-kappaB DNA binding abrogation. Mol. Nutr. Food Res. 2014, 58, 1333-1341. [CrossRef] [PubMed]

47. Dossi, C.G.; Tapia, G.S.; Espinosa, A.; Videla, L.A.; D’Espessailles, A. Reversal of high-fat diet-induced hepatic steatosis by n-3 LCPUFA: Role of PPAR-alpha and SREBP-1c. J. Nutr. Biochem. 2014, 25, 977-984. [CrossRef] [PubMed] 
48. Morimoto, M.; Zern, M.A.; Hagbjörk, A.L.; Ingelman-Sundberg, M.; French, S.W. Fish oil, alcohol, and liver pathology: Role of cytochrome P450 2E1. Proc. Soc. Exp. Biol. Med. 1994, 207, 197-205. [CrossRef] [PubMed]

49. Wada, S.; Yamazaki, T.; Kawano, Y.; Miura, S.; Ezaki, O. Fish oil fed prior to ethanol administration prevents acute ethanol-induced fatty liver in mice. J. Hepatol. 2008, 49, 441-450. [CrossRef] [PubMed]

50. Song, B.J.; Moon, K.H.; Olsson, N.U.; Salem, N., Jr. Prevention of alcoholic fatty liver and mitochondrial dysfunction in the rat by long-chain polyunsaturated fatty acids. J. Hepatol. 2008, 49, 262-273. [CrossRef] [PubMed]

51. Huang, L.L.; Wan, J.B.; Wang, B.; He, C.W.; Ma, H.; Li, T.W.; Kang, J.X. Suppression of acute ethanol-induced hepatic steatosis by docosahexaenoic acid is associated with downregulation of stearoyl-CoA desaturase 1 and inflammatory cytokines. Prostaglandins Leukot. Essent. Fatty Acids 2013, 88, 347-353. [CrossRef] [PubMed]

52. Pawlosky, R.J.; Flynn, B.M.; Salem, N., Jr. The effects of low dietary levels of polyunsaturates on alcohol-induced liver disease in rhesus monkeys. Hepatology 1997, 26, 1386-1392. [CrossRef] [PubMed]

53. Pawlosky, R.J.; Salem, N., Jr. Development of alcoholic fatty liver and fibrosis in rhesus monkeys fed a low n-3 fatty acid diet. Alcohol. Clin. Exp. Res. 2004, 28, 1569-1576. [CrossRef] [PubMed]

54. Turner, R.; McLean, C.H.; Silvers, K.M. Are the health benefits of fish oils limited by products of oxidation? Nutr. Res. Rev. 2006, 19, 53-62. [CrossRef] [PubMed]

55. Dietary Reference Intakes for Energy, Carbohydrate, Fiber, Fat, Fatty Acids, Cholesterol, Protein, and Amino Acids; The National Academy Press: Washington, DC, USA, 2005.

56. Kris-Etherton, P.M.; Taylor, D.S.; Yu-Poth, S.; Huth, P.; Moriarty, K.; Fishell, V.; Hargrove, R.L.; Zhao, G.; Etherton, T.D. Polyunsaturated fatty acids in the food chain in the United States. Am. J. Clin. Nutr. 2000, 71, 179S-188S. [PubMed]

57. Choe, E.; Min, D.B. Chemistry of deep-fat frying oils. J. Food Sci. 2007, 72, R77-R86. [CrossRef] [PubMed]

58. Alexander, J.C. Chemical and biological properties related to toxicity of heated fats. J. Toxicol. Environ. Health 1981, 7, 125-138. [CrossRef] [PubMed]

59. Halvorsen, B.L.; Blomhoff, R. Determination of lipid oxidation products in vegetable oils and marine omega-3 supplements. Food Nutr. Res. 2011. [CrossRef] [PubMed]

60. Perez-Herrera, A.; Rangel-Zuñiga, O.A.; Delgado-Lista, J.; Marin, C.; Perez-Martinez, P.; Tasset, I.; Tunez, I.; Quintana-Navarro, G.M.; Lopez-Segura, F.; Luque de Castro, M.D.; et al. The antioxidants in oils heated at frying temperature, whether natural or added, could protect against postprandial oxidative stress in obese people. Food Chem. 2013, 138, 2250-2259. [CrossRef] [PubMed]

61. Kanner, J. Dietary advanced lipid oxidation endproducts are risk factors to human health. Mol. Nutr. Food Res. 2007, 51, 1094-1101. [CrossRef] [PubMed]

62. Ng, C.Y.; Leong, X.F.; Masbah, N.; Adam, S.K.; Kamisah, Y.; Jaarin, K. Heated vegetable oils and cardiovascular disease risk factors. Vasc. Pharmacol. 2014, 61, 1-9. [CrossRef] [PubMed]

63. Perez-Herrera, A.; Delgado-Lista, J.; Torres-Sanchez, L.A.; Rangel-Zuñiga, O.A.; Camargo, A.; Moreno-Navarrete, J.M.; Garcia-Olid, B.; Quintana-Navarro, G.M.; Alcala-Diaz, J.F.; Muñoz-Lopez, C.; et al . The postprandial inflammatory response after ingestion of heated oils in obese persons is reduced by the presence of phenol compounds. Mol. Nutr. Food Res. 2012, 56, 510-514. [CrossRef] [PubMed]

64. Owu, D.U.; Osim, E.E.; Ebong, P.E. Serum liver enzymes profile of Wistar rats following chronic consumption of fresh or oxidized palm oil diets. Acta Trop. 1998, 69, 65-73. [CrossRef]

65. Nwanguma, B.C.; Achebe, A.C.; Ezeanyika, L.U.; Eze, L.C. Toxicity of oxidized fats II: Tissue levels of lipid peroxides in rats fed a thermally oxidized corn oil diet. Food Chem. Toxicol. 1999, 37, 413-416. [CrossRef]

66. Shibayama, Y. Hepatotoxicity of heated and oxygenated corn oil. Exp. Toxicol. Pathol. 1992, 44, $255-258$. [CrossRef]

67. Varma, P.S.; Aruna, K.; Rukkumani, R.; Menon, V.P. Alcohol and thermally oxidized pufa induced oxidative stress: Role of $N$-acetyl cysteine. Ital. J. Biochem. 2004, 53, 10-15. [PubMed]

68. Aruna, K.; Rukkumani, R.; Varma, P.S.; Menon, V.P. Therapeutic role of Cuminum cyminum on ethanol and thermally oxidized sunflower oil induced toxicity. Phytother. Res. 2005, 19, 416-421. [CrossRef] [PubMed]

69. Rukkumani, R.; Aruna, K.; Varma, P.S.; Viswanathan, P.; Rajasekaran, K.N.; Menon, V.P. Protective role of a novel curcuminoid on alcohol and PUFA-induced hyperlipidemia. Toxicol. Mech. Methods 2005, 15, 227-234. [CrossRef] [PubMed] 
70. Rukkumani, R.; Aruna, K.; Varma, P.S.; Menon, V.P. Influence of ferulic acid on circulatory prooxidant-antioxidant status during alcohol and PUFA induced toxicity. J. Physiol. Pharmacol. 2004, 55, 551-561. [PubMed]

71. Latha, P.; Chaitanya, D.; Rukkumani, R. Protective effect of Phyllanthus niruri on alcohol and heated sunflower oil induced hyperlipidemia in Wistar rats. Toxicol. Mech. Methods 2010, 20, 498-503. [CrossRef] [PubMed]

72. Ringseis, R.; Muschick, A.; Eder, K. Dietary oxidized fat prevents ethanol-induced triacylglycerol accumulation and increases expression of PPARalpha target genes in rat liver. J. Nutr. 2007, 137, 77-83. [PubMed]

73. Feldstein, A.E.; Lopez, R.; Tamimi, T.A.; Yerian, L.; Chung, Y.M.; Berk, M.; Zhang, R.; McIntyre, T.M.; Hazen, S.L. Mass spectrometric profiling of oxidized lipid products in human nonalcoholic fatty liver disease and nonalcoholic steatohepatitis. J. Lipid Res. 2010, 51, 3046-3054. [CrossRef] [PubMed]

74. Zein, C.O.; Yerian, L.M.; Gogate, P.; Lopez, R.; Kirwan, J.P.; Feldstein, A.E.; McCullough, A.J. Pentoxifylline improves nonalcoholic steatohepatitis: A randomized placebo-controlled trial. Hepatology 2011, 54, 1610-1619. [CrossRef] [PubMed]

75. Raszeja-Wyszomirska, J.; Safranow, K.; Milkiewicz, M.; Milkiewicz, P.; Szynkowska, A.; Stachowska, E. Lipidic last breath of life in patients with alcoholic liver disease. Prostaglandins Other Lipid Mediat. 2012, 99, 51-56. [CrossRef] [PubMed]

76. Yang, L.; Latchoumycandane, C.; McMullen, M.R.; Pratt, B.T.; Zhang, R.; Papouchado, B.G.; Nagy, L.E.; Feldstein, A.E.; McIntyre, T.M. Chronic alcohol exposure increases circulating bioactive oxidized phospholipids. J. Biol. Chem. 2010, 285, 22211-22220. [CrossRef] [PubMed]

77. Liu, H.; Beier, J.I.; Arteel, G.E.; Ramsden, C.E.; Feldstein, A.E.; McClain, C.J.; Kirpich, I.A. Transient receptor potential vanilloid 1 gene deficiency ameliorates hepatic injury in a mouse model of chronic binge alcohol-induced alcoholic liver disease. Am. J. Pathol. 2015, 185, 43-54. [CrossRef] [PubMed]

78. Patwardhan, A.M.; Akopian, A.N.; Ruparel, N.B.; Diogenes, A.; Weintraub, S.T.; Uhlson, C.; Murphy, R.C.; Hargreaves, K.M. Heat generates oxidized linoleic acid metabolites that activate TRPV1 and produce pain in rodents. J. Clin. Investig. 2010, 120, 1617-1626. [CrossRef] [PubMed]

79. Patwardhan, A.M.; Scotland, P.E.; Akopian, A.N.; Hargreaves, K.M. Activation of TRPV1 in the spinal cord by oxidized linoleic acid metabolites contributes to inflammatory hyperalgesia. Proc. Natl. Acad. Sci. USA 2009, 106, 18820-18824. [CrossRef] [PubMed]

80. Whitman, W.B.; Coleman, D.C.; Wiebe, W.J. Prokaryotes: The unseen majority. Proc. Natl. Acad. Sci. USA 1998, 95, 6578-6583. [CrossRef] [PubMed]

81. Tremaroli, V.; Backhed, F. Functional interactions between the gut microbiota and host metabolism. Nature 2012, 489, 242-249. [CrossRef] [PubMed]

82. Nicholson, J.K.; Holmes, E.; Kinross, J.; Burcelin, R.; Gibson, G.; Jia, W.; Pettersson, S. Host-gut microbiota metabolic interactions. Science 2012, 336, 1262-1267. [CrossRef] [PubMed]

83. Mutlu, E.; Keshavarzian, A.; Engen, P.; Forsyth, C.B.; Sikaroodi, M.; Gillevet, P. Intestinal dysbiosis: A possible mechanism of alcohol-induced endotoxemia and alcoholic steatohepatitis in rats. Alcohol. Clin. Exp. Res. 2009, 33, 1836-1846. [CrossRef] [PubMed]

84. Mutlu, E.A.; Gillevet, P.M.; Rangwala, H.; Sikaroodi, M.; Naqvi, A.; Engen, P.A.; Kwasny, M.; Lau, C.K.; Keshavarzian, A. Colonic microbiome is altered in alcoholism. Am. J. Physiol. Gastrointest. Liver Physiol. 2012, 302, G966-G978. [CrossRef] [PubMed]

85. Yan, A.W.; Fouts, D.E.; Brandl, J.; Stärkel, P.; Torralba, M.; Schott, E.; Tsukamoto, H.; Nelson, K.E.; Brenner, D.A.; Schnabl, B. Enteric dysbiosis associated with a mouse model of alcoholic liver disease. Hepatology 2011, 53, 96-105. [CrossRef] [PubMed]

86. Bull-Otterson, L.; Feng, W.; Kirpich, I.; Wang, Y.; Qin, X.; Liu, Y.; Gobejishvili, L.; Joshi-Barve, S.; Ayvaz, T.; Petrosino, J.; et al. Metagenomic analyses of alcohol induced pathogenic alterations in the intestinal microbiome and the effect of Lactobacillus rhamnosus GG treatment. PLoS ONE 2013, 8, e53028. [CrossRef] [PubMed]

87. Chen, P.; Stärkel, P.; Turner, J.R.; Ho, S.B.; Schnabl, B. Dysbiosis-induced intestinal inflammation activates tumor necrosis factor receptor I and mediates alcoholic liver disease in mice. Hepatology 2015, 61, 883-894. [CrossRef] [PubMed] 
88. Shi, X.; Wei, X.; Yin, X.; Wang, Y.; Zhang, M.; Zhao, C.; Zhao, H.; McClain, C.J.; Feng, W.; Zhang, X. Hepatic and fecal metabolomic analysis of the effects of Lactobacillus rhamnosus GG on alcoholic fatty liver disease in mice. J. Proteome Res. 2015, 14, 1174-1182. [CrossRef] [PubMed]

89. Kirpich, I.A.; Solovieva, N.V.; Leikhter, S.N.; Shidakova, N.A.; Lebedeva, O.V.; Sidorov, P.I.; Bazhukova, T.A.; Soloviev, A.G.; Barve, S.S.; McClain, C.J.; et al. Probiotics restore bowel flora and improve liver enzymes in human alcohol-induced liver injury: A pilot study. Alcohol 2008, 42, 675-682. [CrossRef] [PubMed]

90. Hildebrandt, M.A.; Hoffmann, C.; Sherrill-Mix, S.A.; Keilbaugh, S.A.; Hamady, M.; Chen, Y.Y.; Knight, R.; Ahima, R.S.; Bushman, F.; Wu, G.D. High-fat diet determines the composition of the murine gut microbiome independently of obesity. Gastroenterology 2009. [CrossRef] [PubMed]

91. Turnbaugh, P.J.; Bäckhed, F.; Fulton, L.; Gordon, J.I. Diet-induced obesity is linked to marked but reversible alterations in the mouse distal gut microbiome. Cell Host Microbe 2008, 3, 213-223. [CrossRef] [PubMed]

92. Turnbaugh, P.J.; Ridaura, V.K.; Faith, J.J.; Rey, F.E.; Knight, R.; Gordon, J.I. The effect of diet on the human gut microbiome: A metagenomic analysis in humanized gnotobiotic mice. Sci. Transl. Med. 2009. [CrossRef] [PubMed]

93. De Wit, N.; Derrien, M.; Bosch-Vermeulen, H.; Oosterink, E.; Keshtkar, S.; Duval, C.; de Vogel-van den Bosch, J.; Kleerebezem, M.; Müller, M.; van der Meer, R. Saturated fat stimulates obesity and hepatic steatosis and affects gut microbiota composition by an enhanced overflow of dietary fat to the distal intestine. Am. J. Physiol. Gastrointest. Liver Physiol. 2012, 303, G589-G599. [CrossRef] [PubMed]

94. Wu, G.D.; Chen, J.; Hoffmann, C.; Bittinger, K.; Chen, Y.Y.; Keilbaugh, S.A.; Bewtra, M.; Knights, D.; Walters, W.A.; Knight, R.; et al. Linking long-term dietary patterns with gut microbial enterotypes. Science 2011, 334, 105-108. [CrossRef] [PubMed]

95. Duncan, S.H.; Lobley, G.E.; Holtrop, G.; Ince, J.; Johnstone, A.M.; Louis, P.; Flint, H.J. Human colonic microbiota associated with diet, obesity and weight loss. Int. J. Obes. 2008, 32, 1720-1724. [CrossRef] [PubMed]

96. David, L.A.; Maurice, C.F.; Carmody, R.N.; Gootenberg, D.B.; Button, J.E.; Wolfe, B.E.; Ling, A.V.; Devlin, A.S.; Varma, Y.; Fischbach, M.A.; et al. Diet rapidly and reproducibly alters the human gut microbiome. Nature 2014, 505, 559-563. [CrossRef] [PubMed]

97. Kirpich, I.; Petrosino, J.; Ajami, N.; Feng, W.; Wang, Y.; Liu, Y.; Beier, J.; Barve, S.; Yin, X.; Wei, X.; et al. Saturated and unsaturated dietary fats differentially modulate ethanol-induced changes in gut microbiome and metabolome in a mouse model of alcoholic liver disease. Am. J. Pathol. 2015, accepted.

98. Vanek, V.W.; Seidner, D.L.; Allen, P.; Bistrian, B.; Collier, S.; Gura, K.; Miles, J.M.; Valentine, C.J.; Kochevar, M.; Novel Nutrient Task Force, Intravenous Fat Emulsions Workgroup; et al. A.S.P.E.N. position paper: Clinical role for alternative intravenous fat emulsions. Nutr. Clin. Pract. 2012, 27, 150-192. [CrossRef] [PubMed]

99. Cresci, G.A.; Bush, K.; Nagy, L.E. Tributyrin supplementation protects mice from acute ethanol-induced gut injury. Alcohol. Clin. Exp. Res. 2014, 38, 1489-1501. [CrossRef] [PubMed]

(C) 2016 by the authors; licensee MDPI, Basel, Switzerland. This article is an open access article distributed under the terms and conditions of the Creative Commons by Attribution (CC-BY) license (http://creativecommons.org/licenses/by/4.0/). 